\title{
A Flow System for Spectrophotometric Multidetermination in Water Exploiting Reagent Injection
}

\author{
Patrícia B. Martelli", Fábio R. P. Rocha , Rejane C. P. Gorga and Boaventura F. Reis* \\ Centro de Energia Nuclear na Agricultura, Universidade de São Paulo, CP 96, 13400-970 Piracicaba - SP, Brazil
}

\begin{abstract}
Um sistema de análise em fluxo é proposto para a multideterminação espectrofotométrica em águas. Alíquotas dos reagentes $(25-75 \mu \mathrm{L})$ foram inseridas no fluxo de amostra, aumentando a sensibilidade em até 4,5 vezes e reduzindo o consumo dos reagentes em 12 vezes em média. O sistema permite a determinação de fosfato $\left(0,25-5,0 \mathrm{mg} \mathrm{L}^{-1}\right)$, compostos fenólicos $\left(0,10-1,0 \mathrm{mg} \mathrm{L}^{-1}\right)$, nitrito $\left(0,050-0,50 \mathrm{mg} \mathrm{L}^{-1}\right)$, sulfeto $\left(0,10-1,0 \mathrm{mg} \mathrm{L}^{-1}\right)$ e ferro total $\left(1,0-5,0 \mathrm{mg} \mathrm{L}^{-1}\right)$ sem alteração da configuração do módulo de análise. Limites de detecção de $150 \mu \mathrm{g} \mathrm{L}^{-1} \mathrm{PO}_{4}^{3-}, 10 \mu \mathrm{g} \mathrm{L}^{-1}$ fenol, $2 \mu \mathrm{g} \mathrm{L}{ }^{-1}$ $\mathrm{NO}_{2}^{-}, 20 \mu \mathrm{g} \mathrm{L}^{-1}$ sulfeto e $15 \mu \mathrm{g} \mathrm{L}^{-1} \mathrm{Fe}^{3+}$ foram estimados a nível de confiança de 99,7 \%. Os coeficientes de variação foram inferiores a $4 \%(n=20)$. Resultados obtidos para amostras de águas de rios e lagos foram concordantes com os obtidos empregando sistemas com adição contínua de reagentes, a nível de confiança de $95 \%$.
\end{abstract}

A flow system for spectrophotometric multidetermination in waters is proposed. Reagent aliquots (25-75 $\mu \mathrm{L})$ were inserted into the sample stream, allowing up to 4.5 -fold increase in sensitivity and an average 12-fold reduction in reagent consumption. The system allows the determination of phosphate $\left(0.25-5.0 \mathrm{mg} \mathrm{L}^{-1}\right)$, phenols $\left(0.10-1.0 \mathrm{mg} \mathrm{L}^{-1}\right)$, nitrite $\left(0.050-0.50 \mathrm{mg} \mathrm{L}^{-1}\right)$, sulphide $\left(0.10-1.0 \mathrm{mg} \mathrm{L}^{-1}\right)$ and total iron $\left(1.0-5.0 \mathrm{mg} \mathrm{L}^{-1}\right)$ without changing the flow manifold. Detection limits of $150 \mu \mathrm{g} \mathrm{L}^{-1} \mathrm{PO}_{4}^{3-}, 10 \mu \mathrm{g} \mathrm{L}^{-1}$ phenol, $2 \mu \mathrm{g} \mathrm{L}^{-1} \mathrm{NO}_{2}^{-}, 20 \mu \mathrm{g} \mathrm{L}^{-1}$ sulphide and $15 \mu \mathrm{g} \mathrm{L}^{-1} \mathrm{Fe}^{3+}$ were estimated at the $99.7 \%$ confidence level. Coefficients of variation were lower than $4 \%(n=20)$. Results for river and lake water samples were in agreement with the obtained with flow systems with continuous reagent addition at the $95 \%$ confidence level.

Keywords: water analysis, flow analysis, reagent injection, multidetermination, multi-element analysis, cleaner analytical method

\section{Introduction}

Nowadays, the consciousness regarding the use of water has increased due to the limited amounts of unpolluted freshwater sources and the high costs to produce potable water from seawater. In some places, most of the consumed water has been previously used. ${ }^{1}$ The Brazilian legislation has established a set of criteria concerning the use of water, including the maximum allowed amounts of toxic species in natural and wastewaters. ${ }^{2}$ A recent discussion has been focused on the establishment of taxes on the use of natural resources and disposal of wastewaters. Moreover, the control of physical and chemical parameters in drinking

* e-mail: reis@cena.usp.br

Present Addresses: \# Departamento Ciências Naturais, Universidade Federal de São João del Rei, Rua Dom Helvécio 74, 36300-000 São João del Rei-MG, Brazil; ' Instituto de Química, Universidade de São Paulo, CP 26077, 05513-970 São Paulo-SP, Brazil water is essential to protect consumers from toxic effects. Thus, the need of reliable analytical methods applicable to water analysis (including in-situ monitoring) is emphasized.

Several analytical methods are available for environmental monitoring. However, in some circumstances, the chemicals employed are even more toxic than the species being monitored, resulting also in some environmental impact. ${ }^{3}$ Thus, a current trend is the development of methodologies less harmful to humans and to the environment (green analytical chemistry). As the substitution of all toxic reagents employed in chemical analysis is not an easy task, the reduction of the employed amounts should be the initial goal. ${ }^{4}$

A lot of flow procedures devoted to water analysis have been presented. ${ }^{5,6}$ These procedures show advantages such as high sampling rate, improved precision, robustness, lower reagent consumption and minor waste generation. ${ }^{5}$ Due to these characteristics, flow systems are very 
attractive for in-situ monitoring. This is an important feature because after sampling, the analyte concentration can change due to physical, chemical and microbiological processes. However, most of the proposed procedures were applied for the determination of single species, which has limited their application for routine and in-field analysis.

Ingenious alternatives have been proposed for multidetermination in flow systems. ${ }^{7}$ However, most of them are complex for routine analysis. Single and robust configurations can be attained by designing polyvalent systems, in which several analytical procedures can be implemented without changing the flow manifold. ${ }^{8,9}$ In this sense, an interesting alternative is the use of flow systems with reagent injection, usually named reversed flow systems (r-FIA). In these systems, small aliquots of concentrated reagents are inserted in continuously flowing samples, minimizing sample dilution and increasing sensitivity. ${ }^{10}$

Several applications of flow systems with reagent injection have been described and both the increase of sensitivity and reduction of reagent amounts have been stressed. ${ }^{10,11}$ Single and ingenious strategies have been presented for in-situ seawater ${ }^{11}$ and freshwater ${ }^{12}$ analysis, including strategies for eliminating refractive index drawbacks in spectrophotometric measurements. ${ }^{13,14}$ Despite their potential for multidetermination, most of the procedures are devoted to the determination of single species.

In this work, a robust procedure is proposed for multiparametric water analysis. The reagent injection strategy was exploited for increasing sensitivity and minimizing the reagent consumption. Spectrophotometric determinations of phosphate, phenols, nitrite, sulphide and total iron were implemented without changing the flow manifold. Iron speciation is also possible by removing the reducing reagent.

\section{Experimental}

\section{Apparatus}

The flow system was constructed with a sliding-bar injector, 0.7-mm i.d. polyethylene tubes and Perspex joint points. An Ismatec IPC-4 peristaltic pump equipped with Tygon tubes was used for fluid propelling. Signals were detected with a 432 Femto spectrophotometer with a 10$\mathrm{mm}$ optical path flow cell ( $80 \mu \mathrm{L}$ inner volume). A strip chart recorder (Cole Parmer) was employed for data monitoring.

\section{Reagents and solutions}

All solutions were prepared with distillated and deionized water and analytical grade chemicals. Single analyte $1.00 \mathrm{~g} \mathrm{~L}^{-1}$ stock solutions were prepared from $\mathrm{KH}_{2} \mathrm{PO}_{4}, \mathrm{C}_{6} \mathrm{H}_{6} \mathrm{O}, \mathrm{NaNO}_{2}$, and $\mathrm{Na}_{2} \mathrm{~S} .9 \mathrm{H}_{2} \mathrm{O}$. Phosphate salt was dried at $110{ }^{\circ} \mathrm{C}$ for $2 \mathrm{~h}$ before weighting. Phenol and nitrite stock solutions were standardized with sodium hydroxide and potassium permanganate, respectively. Iodometry was employed for sulfide standardization. Iron $1.00 \mathrm{~g} \mathrm{~L}^{-1}$ stock solution was prepared from the metal dissolved with $6.0 \mathrm{~mol} \mathrm{~L}^{-1}$ hydrochloric acid. Reference solutions within the ranges $0.25-5.0 \mathrm{mg} \mathrm{L}^{-1} \mathrm{PO}_{4}^{3-}, 0.10-$ $1.0 \mathrm{mg} \mathrm{L}^{-1}$ phenol, $0.10-0.50 \mathrm{mg} \mathrm{L}^{-1} \mathrm{NO}_{2}^{-}$and $1.0-5.0$ $\mathrm{mg} \mathrm{L}^{-1} \mathrm{Fe}(\mathrm{III})$ were prepared by appropriated dilutions.

Phosphate chromogenic reagents were $4.4 \mathrm{mmol} \mathrm{L}^{-1}$ $\mathrm{SnCl}_{2}$ plus $0.30 \mathrm{~mol} \mathrm{~L}^{-1} \mathrm{HCl}\left(\mathrm{R}_{1}\right)$ and $8.0 \mathrm{mmol} \mathrm{L}^{-1}$ ammonium molybdate plus $2.0 \mathrm{~mol} \mathrm{~L}^{-1} \mathrm{H}_{2} \mathrm{SO}_{4}\left(\mathrm{R}_{2}\right)$. Reagents for phenols determination were $5.0 \mathrm{mmol} \mathrm{L}^{-1} 4$ aminoantipyrine (4-AAP) dissolved in a buffer containing $60 \mathrm{mmol} \mathrm{L}^{-1} \mathrm{NaHCO}_{3}$ plus $80 \mathrm{mmol} \mathrm{L}^{-1} \mathrm{H}_{3} \mathrm{BO}_{3}$ at $\mathrm{pH} 10$ $\left(\mathrm{R}_{1}\right)$ and $6.0 \mathrm{mmol} \mathrm{L}^{-1} \mathrm{~K}_{3}\left[\mathrm{Fe}(\mathrm{CN})_{6}\right]\left(\mathrm{R}_{2}\right)$. Chromogenic reagent for nitrite determination was a solution containing $0.10 \mathrm{~mol} \mathrm{~L}^{-1}$ sulfanilamide, $3.5 \mathrm{mmol} \mathrm{L}^{-1} \mathrm{~N}-(1$ naphthyl)ethylenediamine dihydrochloride (NED) and $0.50 \mathrm{~mol} \mathrm{~L}^{-1} \mathrm{HClO}_{4}\left(\mathrm{R}_{1}\right)$. Sulphide was determined with a $4.8 \mathrm{mmol} \mathrm{L}^{-1}$ DMPD solution $\left(\mathrm{R}_{1}\right)$, prepared from N,N'dimethyl-1,4-phenylenediamine dihydrochloride. $\mathrm{R}_{2}$ reagent was $25 \mathrm{mmol} \mathrm{L}^{-1} \mathrm{FeCl}_{3}$ plus $1.0 \mathrm{~mol} \mathrm{~L}^{-1} \mathrm{HCl}$. Solutions for iron determination were $12 \mathrm{mmol} \mathrm{L}^{-1} 1,10$ phenantroline (phen) in $0.10 \mathrm{~mol} \mathrm{~L}^{-1}$ acetate buffer $\mathrm{pH} 5.0$ $\left(\mathrm{R}_{1}\right)$ and $0.15 \mathrm{~mol} \mathrm{~L}^{-1}$ ascorbic acid $\left(\mathrm{R}_{2}\right)$.

\section{Flow diagram and procedure}

The flow manifold in the sampling position is showed in Figure 1a. Sample or reference solutions (S), flowing at $3.0 \mathrm{~mL} \mathrm{~min}^{-1}$ were employed as carrier. Reagent aliquots were selected through the loops $\mathrm{L}_{1}$ and $\mathrm{L}_{2}(25$ and $75 \mu \mathrm{L}$, respectively). These aliquots were simultaneously inserted in the flowing sample by sliding the central bar of the commutator. The reagents are mixed with the sample by dispersion in the coil (B) and the reaction products are measured with a spectrophotometric detector (D). Different chromogenic reagents were employed for determining each species (see reagents and solutions section). Phenol, iron and nitrite were determined at $525 \mathrm{~nm}$, while phosphate and sulphide were measured at $680 \mathrm{~nm}$.

River and lake water samples were collected near Piracicaba in polyethylene bottles and analyzed in the same day by the proposed procedure and by employing flow systems with continuous reagent addition. Before analysis, samples were filtered through $45-\mathrm{mm}$ cellulose acetate membranes. Samples were spiked with phenol and sulphide immediately before analysis. 
a

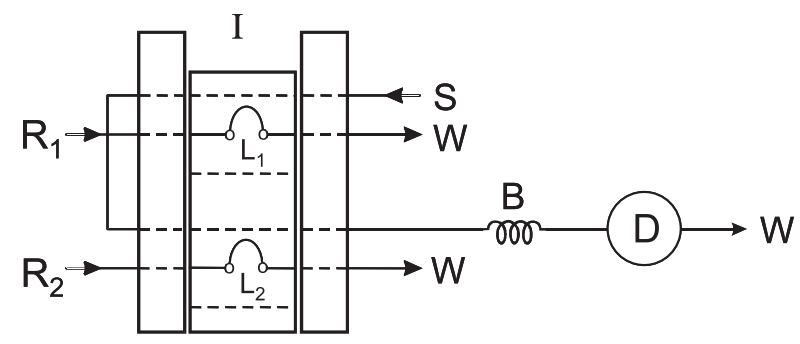

b

\begin{aligned} & initial step \\ & \hline (1) (1) \\ & \hline\end{aligned}

final step
\begin{tabular}{ccc} 
(1) & (3) & 1 \\
\hline
\end{tabular}

\begin{aligned} & initial step C \\ & \hline 1 (2) \\ & \hline\end{aligned}

final step

$$
\text { (1) }
$$

(3)

Figure 1. (a) Flow diagram of the system: I - sliding-bar injector; $S$ -sample or reference solution ( $\left.3.0 \mathrm{~mL} \mathrm{~min}^{-1}\right) ; \mathrm{R}_{1}, \mathrm{R}_{2}$ - chromogenic reagents; $\mathrm{L}_{1}, \mathrm{~L}_{2}$ - reagent loops ( 25 and $75 \mu \mathrm{L}$, respectively); B reaction coil $(150 \mathrm{~cm}, 750 \mu \mathrm{L}) ; \mathrm{D}$ - spectrophotometric detector $(525$ or $680 \mathrm{~nm})$; W - waste vessel. Schematic representation of the sample/reagent dispersion: (b) single-line flow system with sample injection: 1 - reagent (sample concentration $=0$ ); 2 - sample aliquot $\left(C_{A}=C_{0}\right) ; 3$ - sample zone $\left(C_{A}=C_{0} / D\right)$. (c) flow system with reagent injection: 1 - sample $\left(\mathrm{C}_{\mathrm{A}}=\mathrm{C}_{0}\right) ; 2$ - reagent aliquot; 3 - sample zone $\left(\mathrm{C}_{\mathrm{A}} \cong \mathrm{C}_{0}\right)$.

\section{Results and Discussion}

Generally, in flow injection analysis, a discrete sample aliquot is inserted in a carrier solution, yielding a sample zone characterized by a concentration gradient generated by the dispersion process (Figure 1b). The extension of the sample dispersion can be described by the dispersion coefficient (D), defined as the ratio of the sample concentration before $\left(\mathrm{C}_{0}\right)$ and after dispersion $(\mathrm{C})$ : $\mathrm{D}=\mathrm{C}_{0}$ / C. Thus, for maximum sensitivity, the sample dispersion should be limited $(1<\mathrm{D}<3) .{ }^{15}$ On the other hand, in the proposed system, small reagent aliquots were introduced in continuous flowing samples (reagent injection procedure). Therefore, the relation between dispersion and sensitivity is reversed, because the analyte concentration in the reagent zone (initially equal to zero) tends to its maximum value as the dispersion increases (Figure 1c).
Moreover, substitution of the reagents is easier, because they can be directly introduced by the sampling loops $\left(\mathrm{L}_{1}\right.$, $\mathrm{L}_{2}$ - Figure 1a). These characteristics make the procedure very attractive for multi-parametric water analysis.

Most of the procedures exploiting reagent injection are based on the introduction of only one aliquot in the sample stream. When more than one reagent is necessary, the continuous mixing with the sample has been preferred. ${ }^{11,14,16}$ Thus, the favorable features of the reagent injection approach have not been fully exploited. In the proposed system, two reagent aliquots can be introduced in the sample stream, minimizing the consumption of all involved reagents and avoiding sample dilution by confluent streams.

The effect of the manifold parameters (reactor coil length, flow rate and reagent volumes) was evaluated for each species. Sensitivity increases with the reaction coil length in the 50-200 $\mathrm{cm}$ range, resulting also in an increase in the washing time. Thus, a $150-\mathrm{cm}$ reactor coil was selected as a compromise. Similarly, the flow-rate was varied between 1.0 and $4.0 \mathrm{~mL} \mathrm{~min}^{-1}$ and a flow rate of 3.0 $\mathrm{mL} \min ^{-1}$ was established as a compromise between sensitivity and sampling rate. The reagent volumes were selected by taking into account the sensitivity and their consumption, in order to develop greener analytical procedures. In this way, sampling loops of 5 and $15 \mathrm{~cm}$ (25 and $75 \mu \mathrm{L}$ ) were selected for $\mathrm{L}_{1}$ and $\mathrm{L}_{2}$, respectively.

From the absorption spectra of the reaction products under the working conditions, it was determined that the absorption maxima were 690, 510, 540, 670 and $515 \mathrm{~nm}$ for determination of phosphate, phenols, nitrite, sulphide and iron, respectively. However, it was verified that phenols, iron and nitrite could be determined at $525 \mathrm{~nm}$ and phosphate and sulphide at $680 \mathrm{~nm}$ with tolerable lessening in sensitivity. Thus, it was possible to simplify the procedure, making feasible the employment of a single channel spectrophotometer.

The main hindrance observed with the proposed system was the long washing time (up to $130 \mathrm{~s}$ ) observed mainly in the phosphate and phenols determinations. As long washing times could hinder the sampling rate, some experiments were carried out in order to overcome this drawback. An average 2.5-fold reduction in the washing time was observed when the flow-cell volume was reduced from 180 to $80 \mu \mathrm{L}$. Other alternative evaluated was the relocation of the flow cell after attaining the maximum signal, ${ }^{17}$ employing water as washing stream. This allowed a $70 \%$ reduction in the washing time with a $180-\mathrm{mL}$ flow cell. However, a sliding-bar injector with at least three commutation sections is necessary to implement this strategy in conjunct with the reagent injection procedure. 
As the aim of this work was the development of a robust procedure, the employment of a flow cell with lower volume was preferred. In this way, an average sampling rate of 65 determinations per hour was attained. Thus, about $15 \mathrm{~mL}$ of sample is consumed for the determination of the five species.

The linear response ranges, detection limits $(99.7 \%$

Table 1. Analytical features of the proposed system

\begin{tabular}{lcccc}
\hline Species & $\begin{array}{c}\text { Linear range } \\
\left(\mathrm{mg} \mathrm{L}^{-1}\right)\end{array}$ & $\begin{array}{c}\text { Detection limit } \\
\left(\mu \mathrm{g} \mathrm{L}^{-1}\right)\end{array}$ & $\begin{array}{c}\mathrm{CV}^{\mathrm{a}} \\
(\%)\end{array}$ & $\begin{array}{c}\text { Sensitivity } \\
\text { improvement }^{\mathrm{b}}\end{array}$ \\
\hline Phosphate & $0.25-5.0$ & 150 & 1.7 & 4.5 \\
Phenols & $0.10-1.0$ & 10 & 3.8 & 0.9 \\
Nitrite & $0.050-0.50$ & 2 & 1.3 & 4.1 \\
Sulphide & $0.10-1.0$ & 20 & 3.7 & 1.8 \\
Total iron & $1.0-5.0$ & 15 & 3.8 & 1.4 \\
\hline
\end{tabular}

a Coefficient of variation $(\mathrm{n}=20)$; ${ }^{\mathrm{b}}$ Increase in sensitivity in comparison with flow systems with sample injection (continuous reagent addition). The experimental slopes of the analytical curves of the systems were employed. confidence level) and coefficients of variation $(n=20)$ for the determination of the five species are presented in Table 1. With the reagent injection strategy, the sensitivity increases up to 4.5-fold in comparison with those obtained in flow systems with sample injection and continuous reagent introduction. ${ }^{18-22}$

The reagent consumption in the proposed system was estimated by considering the reagent amount per determination and the reagent volume employed for washing the loops $\mathrm{L}_{1}$ and $\mathrm{L}_{2}$. As showed in Table 2, the reagent injection strategy allowed reducing the reagent consumption from 4 to 400 -fold and from 7 to 4000 -fold regarding the conventional FIA systems and batch procedures, respectively. The reagent consumption observed in the proposed system compare favorably to the attained by other greener flow approaches. ${ }^{3}$

The results for multi-parametric analysis of water samples collected near Piracicaba are presented in Table 3. According to the paired Student $t$-test, the results agreed with the obtained by employing flow systems with continuous introduction of reagents at the $95 \%$ confidence level.

Table 2. Reagent amounts consumed by the proposed method by flow systems with continuous reagent addition ${ }^{18-22}$ and by batch procedures ${ }^{23}$

\begin{tabular}{|c|c|c|c|c|}
\hline \multirow[b]{2}{*}{ Species } & \multirow[b]{2}{*}{ Reagent } & \multicolumn{3}{|c|}{ Amount of reagent (mg per determination) } \\
\hline & & Proposed method ${ }^{\mathrm{a}}$ & Confluent systems & Batch methods \\
\hline Phosphate & $\begin{array}{l}\left(\mathrm{NH}_{4}\right)_{6} \mathrm{Mo}_{7} \mathrm{O}_{24} \cdot 4 \mathrm{H}_{2} \mathrm{O} \\
\mathrm{SnCl}_{2} 2 \mathrm{H}_{2} \mathrm{O} \\
\text { ascorbic acid }\end{array}$ & $\begin{array}{c}0.50 \\
0.15 \\
-\end{array}$ & $\frac{3.1}{25}$ & $\begin{array}{c}48 \\
12.5 \\
-\end{array}$ \\
\hline Phenols & $\begin{array}{l}\mathrm{K}_{3}\left[\mathrm{Fe}(\mathrm{CN})_{6}\right] \\
\text { 4-aminoantipyrine }\end{array}$ & $\begin{array}{c}0.010 \\
0.15\end{array}$ & $\begin{array}{c}2.4 \\
0.80\end{array}$ & $\begin{array}{l}40 \\
60\end{array}$ \\
\hline Nitrite & $\begin{array}{l}\text { sulfanilamide } \\
\text { NED }\end{array}$ & $\begin{array}{c}3.0 \\
0.15\end{array}$ & $\begin{array}{l}13 \\
0.8\end{array}$ & $\begin{array}{l}20 \\
2.0\end{array}$ \\
\hline Sulphide & $\begin{array}{l}\text { DMPD } \\
\mathrm{FeCl}_{3} \cdot 6 \mathrm{H}_{2} \mathrm{O}\end{array}$ & $\begin{array}{l}0.15 \\
0.32\end{array}$ & $\begin{array}{c}1.1 \\
130\end{array}$ & $\begin{array}{r}1.9 \\
375\end{array}$ \\
\hline Total iron & $\begin{array}{l}\text { 1,10-phenatroline } \\
\text { ascorbic acid } \\
\mathrm{NH}_{2} \mathrm{OH} . \mathrm{HCl}\end{array}$ & $\begin{array}{c}0.36 \\
1.5 \\
-\end{array}$ & $\begin{array}{l}1.5 \\
6.0 \\
-\end{array}$ & $\frac{10}{100}$ \\
\hline
\end{tabular}

${ }^{a}$ Estimate by considering the reagent volume and the washing step of the loops.

Table 3. Determination of phosphate, phenols, nitrite, sulphide and total iron in waters by the proposed method and reference procedures (flow systems with continuous reagent addition. ${ }^{18-22}$ Concentrations in $\mu \mathrm{g} \mathrm{L}^{-1}$ (mean values and uncertainties, $\mathrm{n}=3$ )

\begin{tabular}{|c|c|c|c|c|c|c|c|c|c|c|}
\hline \multirow[b]{2}{*}{ sample } & \multicolumn{2}{|c|}{ phosphate } & \multicolumn{2}{|c|}{ phenols } & \multicolumn{2}{|c|}{ nitrite } & \multicolumn{2}{|c|}{ sulphide } & \multicolumn{2}{|c|}{ iron } \\
\hline & proposed & reference & proposed & reference & proposed & reference & proposed & reference & proposed & reference \\
\hline 1 & $710 \pm 7$ & $710 \pm 10$ & $356 \pm 2$ & \pm 12 & $69.3 \pm 3.0$ & $69.0 \pm 0.1$ & $223 \pm 14$ & $201 \pm 6$ & $652 \pm 18$ & $638 \pm 6$ \\
\hline 2 & $594 \pm 10$ & $569 \pm 10$ & $108 \pm 7$ & \pm 10 & $404 \pm 3$ & $393 \pm 1$ & $982 \pm 8$ & $979 \pm 11$ & $740 \pm 35$ & $751 \pm 13$ \\
\hline 3 & $979 \pm 17$ & $962 \pm 20$ & $329 \pm 8$ & \pm 6 & $90.2 \pm 3.0$ & $94.2 \pm 1.7$ & $335 \pm$ & $343 \pm 1$ & $1570 \pm 7$ & $1620 \pm 1$ \\
\hline 4 & $255 \pm 13$ & $273 \pm 15$ & $112 \pm 1$ & $91.0 \pm 1$ & $310 \pm 3$ & $308 \pm 1$ & $854 \pm$ & $870 \pm 6$ & $3180 \pm$ & $3040 \pm$ \\
\hline 5 & $940 \pm 17$ & $955 \pm 21$ & $340 \pm 7$ & $307 \pm 6$ & 109 & $93.1 \pm 2.6$ & $669 \pm$ & $706 \pm 11$ & $1540 \pm 2$ & $1560 \pm$ \\
\hline 6 & $701 \pm 6$ & $693 \pm 6$ & $109 \pm 6$ & \pm 10 & $62.3 \pm 5.2$ & $44.9 \pm 1.0$ & $468 \pm 6$ & $450 \pm 6$ & $1240 \pm 4$ & $1390 \pm 1$ \\
\hline
\end{tabular}




\section{Conclusions}

A simple and robust flow system was proposed for multiparametric spectrophotometric water analysis, exploiting reagent injection. The strategy was demonstrated for the determination of phosphate, phenols, nitrite, sulphide and total iron, exploiting chemistries similar to the recommended by the Standard Methods for the Examination of Water and Wastewater as well as the US Environmental Protection Agency. However, any other species can be determined without changing the flow manifold. If more than two reagents are necessary, additional aliquots can be introduced by employing a sliding-bar injector with more than two commutation sections. Alternatively, the reagents can be previously mixed before their introduction in the sample stream. For lab-analysis, a multichannel spectrophotometer (such as a diode array spectrophotometer) could be employed for measurement of the reaction products in their absorption maxima, avoiding the need of manual changing of wavelength. In-field monitoring is also possible due to the reliability of the flow system and the minimization of both the reagent consumption and waste generation. In this sense, photometers with multi-color light emitting diodes (LED) could be employed.

\section{Acknowledgements}

The authors acknowledge the financial support from the Brazilian agencies CNPq and FAPESP.

\section{References}

1. Baird, C.; Environmental Chemistry, W.H. Freeman: New York, 1995.

2. Conselho Nacional do Meio Ambiente (CONAMA), resolução $\mathrm{n}^{\circ}$ 020/86. http://www.mma.gov.br; accessed in July 2002.

3. Rocha, F.R.P.; Nóbrega, J.A.; Fatibello-Filho, O.; Green Chem. 2001, 3, 216.

4. de la Guardia, M.; Ruzicka, J.; Analyst 1995, 120, 17N.

5. Andrew, K.N.; Blundell, N.J.; Price, D.; Worsfold, P.J.; Anal. Chem. 1994, 66, 917A.
6. Cerdà, V.; Estela, J.M.; Forteza, R.; Cladera, A.; Becerra, E.; Altimira, P.; Sitjar, P.; Talanta 1999, 50, 695.

7. Kuban, V.; Crit. Rev. Anal. Chem. 1992, 23, 15.

8. Silva, F.V.; Nogueira, A.R.; Souza, G.B.; Zagatto, E.A.G.; Anal. Chim. Acta 1998, 39, 370

9. Rocha, F.R.P.; Martelli, P.B.; Reis, B.F.; Anal. Chim. Acta 2001, $438,11$.

10. Johnson, K.S.; Petty, R.L.; Anal. Chem. 1982, 54, 1185.

11. Shpigun, L.K.; Kolotyrkina, I. Y.; Zolotov, Y.A.; Anal. Chim. Acta 1992, 261, 307.

12. Worsfold, P.J.; Clinch, J.R.; Casey, H.; Anal. Chim. Acta 1987, 197, 43.

13. Thonsen, J.; Johnson, K.S.; Petty, R.L.; Anal. Chem. 1983, 55, 2378.

14. Auflitsch, S.; Peat, D.M.W.; McKelvie, I.D.; Worsfold, P.J.; Analyst 1997, 122, 1477.

15. Ruzicka, J.; Hansen, E.H.; Flow Injection Analysis, $2^{\text {nd }}$ ed., John Wiley and Sons: New York, 1988.

16. Liu, R.; Wang, H.; Sun, A.; Liu, D.; Talanta 1997, 45, 405.

17. Zagatto, E.A.G.; Bergamin-Filho, H.; Brienza, S.M.B.; Arruda, M.A.Z.; Nogueira, A.R.A; Lima, J.L.F.C.; Anal. Chim. Acta 1992, 261, 59

18. Trojanowicz, M.; Worsfold, P.J.; Clinch, J.R.; Trends Anal. Chem. 1988, 7, 301.

19. Frenzel, W.; Oleksy-Frenzel, J.; Moller, J.; Anal. Chim. Acta 1992, 261, 253.

20. Giné, M.F.; Bergamin-Filho, H.; Zagatto, E.A.G.; Reis, B.F.; Anal. Chim. Acta 1980, 114, 191.

21. Leggett, D.J.; Chen, N.H.; Mahadevappa, D.S.; Anal. Chim. Acta 1991, 128, 163.

22. Mortatti, J.; Krug, F.J.; Pessenda, L.C.R.; Zagatto, E.A.G.; Jorgensen, S.S.; Analyst 1982, 107, 659.

23. Eaton, A.D.; Clesceri, L.S.; Greenberg, A.E.; Standard Methods for the Examination of Water and Wastewater, $19^{\text {th }}$ ed., American Public Health Association: Washington, 1995.

Received: August 3, 2001

Published on the web: August 23, 2002

FAPESP helped in meeting the publication costs of this article. 